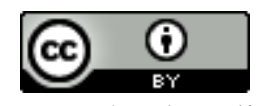

Esta obra está sob o direito de Licença Creative Commons Atribuição 4.0 Internacional.

\title{
UMA ANÁLISE REFLEXIVA SOBRE OS AVANÇOS E RETROCESSOS DA EDUCAÇÃO INCLUSIVA: práticas inovadoras com foco na formação
}

\author{
Maria Angela da Silva Alves ${ }^{1}$ \\ Aline pereira Barros ${ }^{2}$ \\ Fabia de Oliveira Silva ${ }^{3}$ \\ Wilamo de Omena Lopes Junior ${ }^{4}$
}

\section{RESUMO}

O questionamento a respeito da inclusão de educandos com necessidades educacionais especiais em instituições escolares públicas passou a ganhar um grande espaço ultimamente. A teoria de inclusão vem tendo um espaço para questionamento em todo nosso país, sob distintos pontos de vista e olhares teóricos. Entretanto, ao avaliar mais a fundo esse tema tão relevante, é possível identificar que o desenvolvimento da inclusão educacional possui como meta a mobilização da população para uma nova visão diante das singularidades do indivíduo, nomeando-as com uma estima a ser reconhecida por todos os que fazem a educação, pais e família dessas crianças com necessidades especiais, levando em consideração que a primordial propriedade do homem é o pluralismo, e não a equidade ou a igualdade. É possível definir inclusão como sendo um procedimento gradual e interativo. Trata-se de atividade em prol do respeito às particularidades de cada sujeito, disponibilizando alternativas às suas carências e singularidades. A expectativa principal da inclusão é a convicção de que não ocorre à igualdade nos indivíduos, e estas diferenças são responsáveis pelas suas características. O educando passa então a ser entendido como sujeito único, singular e social, que possui história de vida, instituindo-se, portanto, em ser histórico distinto. O objetivo deste trabalho é avaliar os enigmas na ação da inclusão escolar dentro das instituições educacionais públicas e as circunstâncias importantes que brotam com o passar do tempo, afinal cada membro, com suas ações e reflexões, vão intervindo no processo educacional, vai cristalizando ideias, reafirmando conceitos e pré-conceitos, que se trata de demonstração de modo particular e concreto. Frente às avaliações que serão feitas, é necessário avaliar mais a fundo que os ambientes são diferençados de um educando normal para um especial, e carecem de mais cuidado, possuindo características particulares que se deparam com distintos objetivos para cada situação de ensino. Todavia, desse modo se tornará viável presenciar nas ações dos educadores situações de controle a respeito do modo de interagir com esses educandos. É permitido assegurar que diversas instituições de ensino estão (des) orientadas diante das probabilidades da inclusão no

\footnotetext{
1 angelateacher2@hotmail.com

2aline_barros09_@hotmail.com

3 fabia.oliveira1@gmail.com

${ }^{4}$ wilamojr@msn.com
} 
ensino desses alunos com necessidades especiais, especialmente já que esta nova situação determina um reavaliar a respeito do fazer pedagógico, uma modificação da instituição escolar da atualidade para a escola de todos, cercada por respeito ao indivíduo singular e social.

Palavras-chave: Espaço escolar. Inclusão Social. Estratégias.

Submetido em março de 2020 e aceito em maio de 2020. 


\section{INTRODUÇÃO}

Tornar uma educação real, existida e enfrentada para todos, onde todos tenham a oportunidade de desenvolver o saber do apropriado significado de plenitude como cidadãos precisaram possuir uma meta de ampliar o conhecimento cultural.

É possível definir a educação especial como uma educação que atende os portadores de necessidades espaciais, tais como: auditivas, visuais, intelectual, física, sensorial, surdo cegueira e as múltiplas deficiências. Para que estes indivíduos tenham a possibilidade de serem educados e reabilitados, é relevante o entrosamento deles em instituições educacionais especializadas. E que eles tenham acesso a todas as coisas necessárias para alcançar sua ampliação cognitiva. A finalidade da educação especial é ser uma totalidade, e possuir sua importância identificada é relevante para que os educandos possuam desenvolvimento e desempenho educacional aceitável.

É possível perceber que a educação inclusiva está disponível de todos para todos, aonde os tidos como "normais" e os portadores de necessidades especiais terão a oportunidade de ampliar seus saberes interagindo um com os outros. É necessária a dependência entre elas para que aconteça a educação de qualidade.
Em nosso país, a educação inclusiva é atualmente um desafio a ser encarado cotidianamente por todos os trabalhadores da educação.

No entanto, é relevante ressaltar que a definição de inclusão abrange: acolher os portadores de necessidades especiais; proporcionar a intensidade de atendimento nas salas regulares; disponibilizar aos educadores base técnica; entender que é possível os educandos adquirirem conhecimentos juntas, mesmo que possuindo finalidades e metodologias distintas; conduzir o educador a utilizar metodologias criativas de ação com os educandos portadores de necessidades especiais; proporcionar um acolhimento agregado ao educador de sala ordinária do ensino regular. Entretanto, a finalidade da inclusão não significa: conduzir às salas de aula comum as crianças sem a presença do educador especializado; desprezar as carências exclusivas do educando; induzir as crianças a adotarem uma situação singular de desenvolvimento, no mesmo período e para faixa etária generalizada; acabar a recepção de educação especial no período anterior ao indicado; achar que os educadores de salas comuns transmitam conhecimento aos educandos com necessidades especiais sem base técnica.

É através da educação inclusiva que se abarca essas crianças com condição, 
porém é indispensável que os profissionais possuam respaldo quer técnico quer preparatório, para que possa concretizar os objetivos de modo correto. Ao decorrer do processo, a grande fatia dos profissionais

\section{METODOLOGIA}

\section{Características da pesquisa}

Trata-se de uma pesquisa bibliográfica com intensa leitura dos textos e obras, sistematizado por Lessa (2011, p. 20 e 21) “A leitura imanente consiste na decomposição do texto em suas unidades significativas mais elementares: ideias, conceitos, categorias, na busca da trama que articulava tais unidades a uma teoria, hipóteses, teses e proposições, com o intuito de elaborar outras teorias interpretativas".

A Leitura Imanente é um recurso que nos ajuda em estudos sistemáticos de pesquisas acadêmicos, encontrados em forma de livros, teses, dissertações, monografias, artigos, entre outros; bem como em estudos bibliográficos. A utilização e aplicação consecutiva e crítica desta metodologia aperfeiçoa o campo cognitivo que abrange a compreensão e a apreensão dos elementos que estruturam os modos de exprimir e materializar os conhecimentos científicos (BEZERRA, 2015).

De acordo com Vieira (2006, p. 17), “a pesquisa bibliográfica fundamenta-se engajados na educação não tem conhecimento ou debochavam frente a relevância e a diferença da educação especial e a educação inclusiva.

principalmente em análises qualitativas, baseadas em conhecimentos teóricoempíricos que permitem atribuir-lhes cientificidade".

\section{Do ponto de vista dos objetivos}

No que diz respeito aos meios, em relação à abordagem dos objetivos, esta pesquisa é exploratória, que tem a finalidade de proporcionar familiaridade com o problema, tornando-o explícito ou, ainda legitimando a construção de hipóteses (GIL, 2010).

De acordo com o autor acima citado o primordial objetivo da pesquisa exploratória deve ser o aprimoramento das ideias ou a descoberta das instituições.

\section{Do ponto de vista dos procedimentos técnicos e da abordagem do problema}

As metodologias técnicas utilizadas para este estudo foi o levantamento bibliográfico e documental tem por objetivo proporcionar familiaridade com $\mathrm{o}$ problema, tornando-o mais explicitado (LAKATOS; MARCONI, 2001).

Por meio das pesquisas realizadas, de modo sistematizado, em livros, artigos científicos, disponíveis em documentos 